\title{
$\mathrm{CaCl}_{2}, \mathrm{LiCl}$ 及びコロイダルシリカを用いて処理した多孔及び 緻密全熱交換紙の水蒸気透過挙動
}

\author{
延世大学 (韓国 ソウル) 化学工学科 ヨム ボン ヨル，ミン ビョンリョル
}

\section{Water Vapor Transmission Behavior through Porous and Dense Enthalpy Exchange Sheets Treated with $\mathrm{CaCl}_{2}, \mathrm{LiCl}$ and Colloidal Silica}

Bong-Yeol Yeom and Byoung-Ryul Min

Department of chemical engineering, Yonsei University, Seoul, Korea

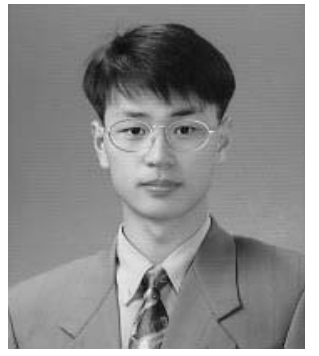

ヨム ボン ヨル

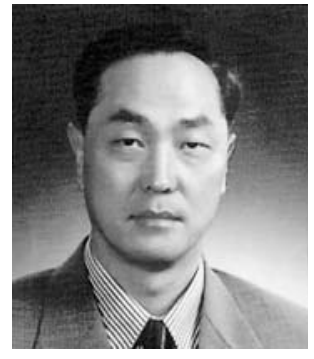

ミン ビョン リョル

This report is concerning the sheet to be utilized to the air-to-air heat exchanger. Observation on the characters of the moisture permeation for two types of the enthalpy sheet (porous and dense enthalpy sheets) has been conducted. To improve the efficiency of the moisture permeation through the enthalpy sheet, the moisture absorbents $\mathrm{CaCl}_{2}, \mathrm{LiCl}$ and colloidal silica have been used. Throughout the wet cup test according to the ASTM standards, the tests of the moisture permeation according to the changes of the air gap have been conducted. For both of the porous and dense enthalpy sheets, it showed 2 to 2.5 times of increase for the permeability of water vapor when the air gap reduced from 13 $\mathrm{mm}$ to $6 \mathrm{~mm}$. Also, according to the treatment of the moisture absorbent, the permeability of water vapor increased, but after the certain amount of the processing no further increase of the permeability was shown. For the dense enthalpy sheet compared with the porous enthalpy sheet, it showed more increase of permeability of water vapor due to the moisture absorbent and also it was seen that the dense enthalpy sheet has the similar permeability of water vapor to the porous enthalpy sheet's when processing the moisture absorbent.

Keywords : air-to-air heat exchanger, enthalpy sheet, wet cup test, air gap, permeability, moisture absorbent

分類: $\mathrm{Y}_{1}$ 基礎化学一般, $\mathrm{Y}_{6}$ 物理化学

\section{Introduction}

Throughout the oil shock in 1970, the demands for the energy efficiency have been dramatically in- creased. Due to these demands, the studies to increase the heat efficiency were continuously conducted and sealing and insulation of the buildings have been enforced. Although the rate of the natural 
ventilation depending on the places are two to 5 times, which is required to maintain the healthy indoor air quality, these efforts are not good enough because of the increasing interest in improving the energy efficiency $^{1)}$.

The air-to-air heat exchanger is the ventilation device to satisfy the energy saving and IAQ improvement and this is being equipped with most of the air conditioning equipments. The air-to-air heat exchanger can be categorized into two types depending on the heat exchange element. One is the sensible heat exchanger made of metal or plastic exchanging only sensible heat and the other is the enthalpy exchanger made of paper or material for the accumulated heat which exchange the sensible and latent heat at the same time. The enthalpy exchanger can also be categorized into permeable plate, energy wheel and rotary dehumidifier ${ }^{2-4)}$. Among the enthalpy exchanger types, the enthalpy exchangers, the simply permeable plate type, which consist of the supply air, exhaust air FAN but do not require the moving parts and can be installed on the ceiling, are mostly used.

Contrary to these increasing use of them, a valuation basis for developing the enthalpy exchange element, which is the main part of the enthalpy exchanger, is not well prepared since the studies and standards of the valuation of the enthalpy exchanger's performance is formed with the element types $^{5-7)}$. A good characteristic of an enthalpy exchanger sheet is to maximize the water vapor transmission and to minimize the permeation of harmful gases, and therefore to improve the performance of enthalpy exchange. Therefore, the performance valuation of the enthalpy exchange element should be conducted before making it to develop the enthalpy exchanger with high quality. In both these parameters, the water vapor transmission (WVTR) is the most important factor in respect of energy saving. The ways of having the water vapor transmission test to measure the accumulated heat are ASTM 96-00 and JIS, and these methods consist of the wet cup method measuring the permeation amount of the water from the internal to the external cell filled with water and the dry cup method measuring the absorption amount of the water from the external to the internal cell filled with $\mathrm{CaO}^{5,6)}$. Both of these methods can only determine the relative water vapor transmission since there is a lack of the approach to the test methods of the resistance caused by water penetration, the resistance of the specimen itself, and the boundary layer resistances to the air layers between both sides of the specimen ${ }^{8}$.

Therefore, in this study, the previous standards have been reviewed to examine the performance of the water vapor transmission, affecting the enthalpy's exchange efficiency and with these improved methods the performance of the enthalpy sheet has been measured. The water vapor transmission of the enthalpy exchange sheet before it is made in was examined.

By evaluating the porous and dense enthalpy exchange sheets, the pore structure of the water vapor transmission according to the pore structure and the influence of the moisture absorbent such as $\mathrm{CaCl}_{2}$, $\mathrm{LiCl}$ and colloidal silica that have been mainly used in liquid desiccant were examined ${ }^{9}$.

\section{Experimental}

\section{1 Enthalpy sheet preparation}

Anhydrous calcium chloride (chemical pure grade) and anhydrous lithium chloride (extra pure grade) used as the moisture absorbent were purchased from Junsei Chemical Co., Ltd (Tokyo, Japan) special purification was used as well. The Colloidal silica stabilized by Na, whose diameter is $10 \mathrm{~nm}-20 \mathrm{~nm}, \mathrm{pH} 9.5^{-}$ $\mathrm{pH} 10$, and viscosity $1.0 \mathrm{mPs}-3.0 \mathrm{mPs}$, is the suspension solution with $20 \%$ of $\mathrm{SiO}_{2}$, and purchased from Nissan Chemical Industries, Ltd. (snowtechs 20, Tokyo, Japan).

The dense and the porous enthalpy exchange sheet have been provided from Mitsubishi Paper Mills Co., Ltd without being proceed in the moisture absorbent and the ultra-pure de-ionized water was used in soak.

The process of the moisture absorbent soak is as below. First of all, after making the moisture absorbent solution at the desired density, the enthalpy exchange sheets were prepared with the standard size $(6 \mathrm{~cm} \times 6 \mathrm{~cm})$ and measured before soak. The surrounding condition was $20^{\circ} \mathrm{C}, 20 \% \mathrm{RH}$. After putting the moisture absorbent solution $(300 \mathrm{ml})$ into the Petri dish, the enthalpy exchange sheet was soak into it for 
3 minutes in order to the moisture absorbent was fully absorbed into the enthalpy exchange sheet. Meanwhile the moisture absorbent solution was covered with the lid to prevent the moisture in the air from flowing into it since the moisture absorbent solution tends to stay equal to the moisture in the air. After handling the moisture absorbent, the sheet was taken out, laid on the glass plate and the moisture absorbent on the enthalpy exchange sheet was removed with the rubber roller. The weight of the enthalpy exchange sheet was measured quickly due to the concerns about the moisture evaporation. The enthalpy exchange sheet was dried with the heat plate and was proceed in heat treatment $\left(120^{\circ} \mathrm{C}-130^{\circ} \mathrm{C}\right)$ to keep it level. Thickness measurements were obtained with a thickness gauge (Mitutoyo, Japan) at a minimum of five positions on an enthalpy sheet. The standard deviation of thickness for each specimen was typically less than $10 \%$. The uptake of the moisture absorbent was determined by the formula as below.

Absorbent uptake $=\left(W_{\text {wet }}-W_{d r y}\right) \times C_{\text {absorbent }}$

where $W_{\text {wet }}$ is the weight of wet enthalpy sheet that was removed excess water and $W_{d r y}$ is the weight of dry enthalpy sheet, and $C_{a b s o r b e n}$ is the weight concentration of absorbent solution.

\subsection{Water vapor transmission measurement}

The schematic diagram of the experimental apparatus of water vapor transmission rate (WVTR) is illustrated in Fig. 1. The technique used to measure WVTR was a modification of the wet cup method described by ASTM E $96-00^{4)}$. In this method the test film covered a Petri dish filled with ultra-pure de-ionized water. The mass of water lost from the dish was observed as a function of time, and the WVTR was calculated from the steady-state region. A window of known area was cut into an acryl resin, and the specimen was attached to the acryl resin with 5 -Minute ${ }^{\circledR}$ epoxy. The acryl resin with a enthalpy exchange sheet was attached with aluminum tape to the top of a plastic Petri dish that was $38.5 \mathrm{~cm}^{2}$ in area. Using a syringe, $48.2 \mathrm{~m} l$ of ultra-pure de-ionized water was added to the Petri dish, and the hole was sealed with aluminum tape. With $48.2 \mathrm{ml}$ of water in the dish, the air gap between water surface and enthalpy sheet was $6 \mathrm{~mm}$. The WVTR at $13 \mathrm{~mm}$ air gap was also measured to examine the effect caused by the air gap. After allowing the epoxy to cure for $1 \mathrm{hr}$, the sample dish was weighed and placed in a constant temperature and humidity air conditioner at $25^{\circ} \mathrm{C} \pm 0.5^{\circ} \mathrm{C}$ and $50 \% \mathrm{RH} \pm 1.5 \% \mathrm{RH}$ with air circulation rate of about $0.5 \mathrm{~m} \mathrm{~s}^{-1}$. The sample dish was periodically removed and weighed. The weight loss as a function of time was recorded. The sample dish was typically removed from the constant temperature and humidity air conditioner for weighing once every hour.

\section{Results and discussion}

\subsection{Water vapor transmission rate}

Representative tests of porous and dense enthalpy sheets treated with $\mathrm{CaCl}_{2}$ are shown in Fig. 2. The water loss as the time passed showed the linear trend and from this trend, the moisture permeation showed the steady-state. All of the tests were checked to be normal after leaving as they were inside the chamber with constant temperature and constant moisture for more than $8 \mathrm{hrs}$ and the water vapor transmission

\section{Constant temperature and humidity conditions: $25^{\circ} \mathrm{C}, 50 \% \mathrm{RH}$}

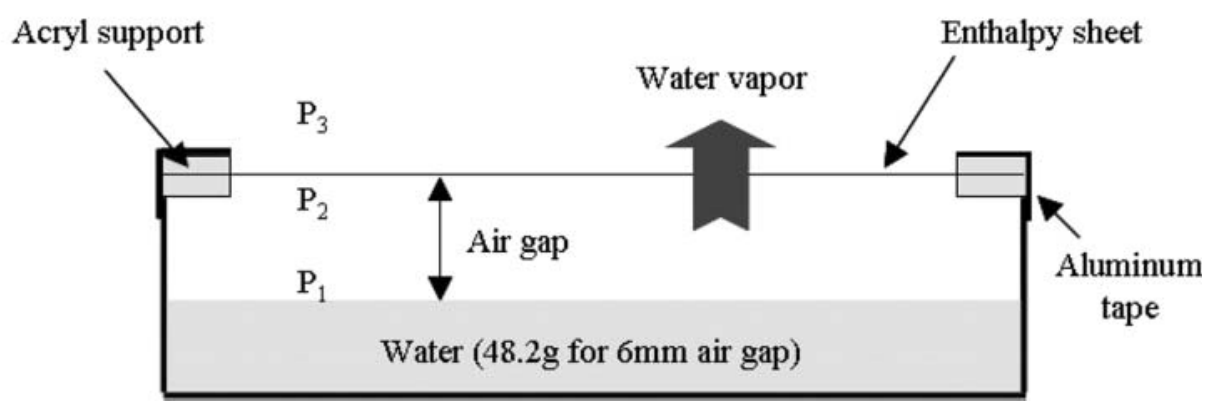

Fig. 1 Schematic diagram of water vapor transmission rate test. 


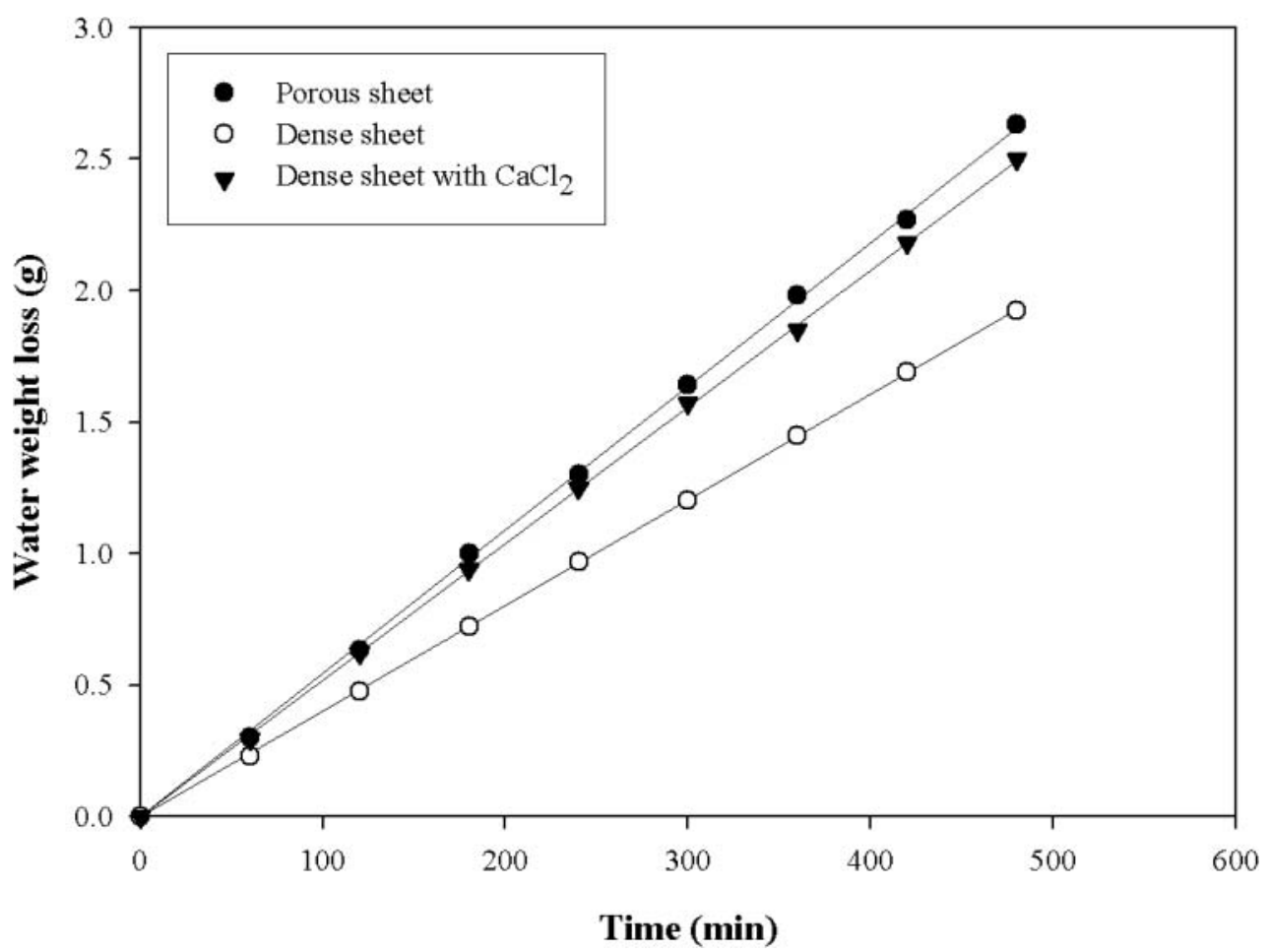

Fig. 2 Weight loss as a function of time in the wet cup test.

rate was resulted from the reduction of the moisture in general condition. Reaching the balance of the moisture inside of the test dish to the test temperature inside of the chamber with the constant temperature and moisture took the first $1 \mathrm{hr}$ and after that all of the tests showed the linear trends.

WVTR as a function of time normalized to the testing area (A) can be calculated as below.

$$
W V T R=\frac{\text { mass } \mathrm{H}_{2} \mathrm{O} \text { lost }}{\text { time } \times \text { area }}=\frac{\text { flux }}{\text { area }}
$$

with units of $\mathrm{g} \mathrm{day}^{-1} \mathrm{~m}^{-2}$. The WVTR is related to a material characteristic, the water vapor permeability, $\Leftrightarrow$, with units of $\mathrm{cm}^{3} \mathrm{~cm} \mathrm{~cm}^{-2} \mathrm{~s}^{-1} \mathrm{cmHg}^{-1}$ as

$$
\wp=W V T R\left(\frac{l}{\Delta p}\right)
$$

where $l$ is the enthalpy sheets thickness $(\mathrm{cm})$ and $\Delta p$ is the pressure difference across the enthalpy sheets $(\mathrm{cmHg})^{4)}$.

Photo. 1 shows WVTR according to the air gap of the porous enthalpy exchange sheet. In the wet cup method of ASTM 96-00 standard, the distance between the specimen and the surface of the water is prescribed as $19 \mathrm{~mm} \pm 6 \mathrm{~mm}^{4}$. This prescription as- sumes the interior of test cell, the distance between the surface of the water and the surface of the specimen is $100 \%$ RH. However, as shown in Fig. 3, at 6 mm air gap, WVTR showed Figures almost 2 times bigger compared at $13 \mathrm{~mm}$, minimum distance prescribed. Showing the different WVTR according to the air gap means that the resistance taken to move up to the surface of the enthalpy exchange sheet from the surface of the water increases since there is the concentration gradient inside of the water permeation cell.

$\mathrm{Hu}$ et al. calculated the water permeation at a stationary air layer with Schirmer's equation ${ }^{8)}$.

$$
\xi_{\text {air }}=\left[\frac{\left(2.306 \times 10^{-5}\right) P_{0}}{R_{v} T P}\right]\left[\frac{T}{273.15}\right]^{1.81}
$$

where $\mathrm{T}$ is the temperature $(\mathrm{K}), \mathrm{P}$ is the ambient pressure $(\mathrm{Pa}), P_{0}$ is the standard atmospheric pressure $(101,325 \mathrm{~Pa})$, and $\Delta p$ is the ideal gas constant (461. $5 \mathrm{~J} \mathrm{~K}^{-1} \mathrm{~kg}^{-1}$ for water). The water vapor transmission rate is obtained from the permeability as

$$
\text { WVTR } \frac{\xi_{\text {air }} \Delta P}{W}
$$

where $\mathrm{W}$ is the thickness of the air layer and $\Delta p$ is the 

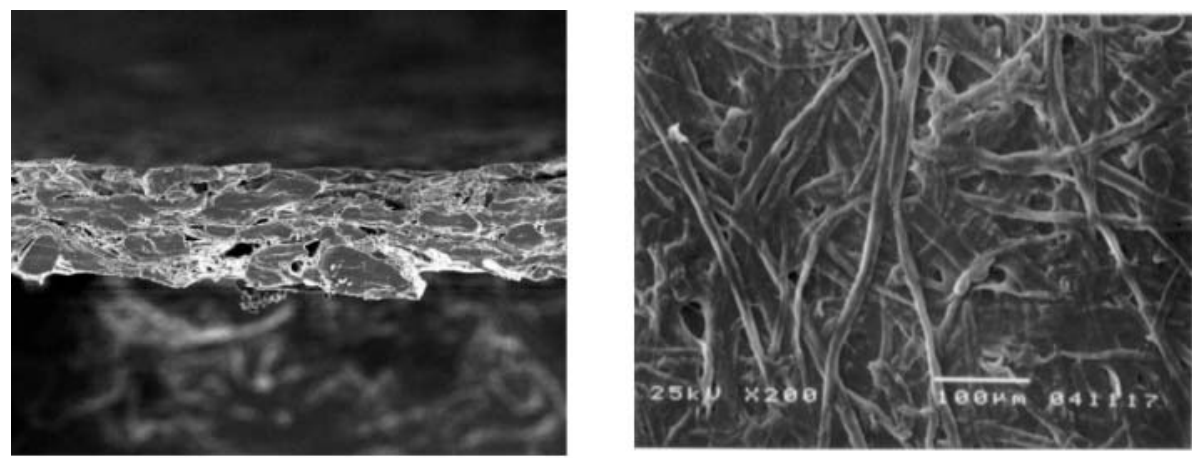

(a) porous enthalpy sheet
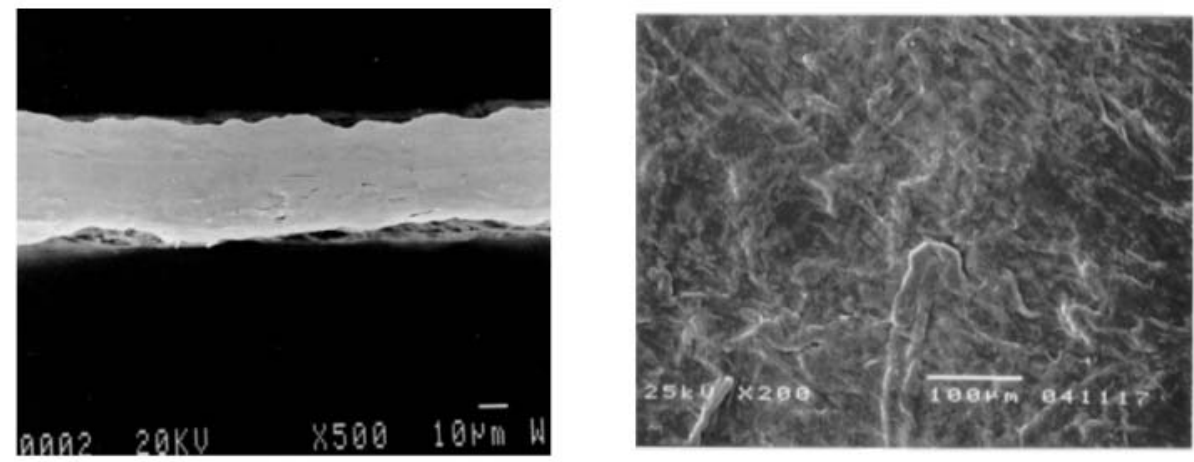

(b) dense enthalpy sheet

Photo. 1 Scanning electron micrographs of enthalpy sheets : (a) porous enthalpy sheet and (b) dense enthalpy sheet (cutting plane photographed by Mitsubishi Paper Mills Ltd.).

pressure difference between the two surfaces. With this formula $6 \mathrm{~mm}$ of the air gap turned to be the optimum by calculating the water vapor permeability to the stagnant layer inside of the test cell. Methods prescribed in ASTM standard can measure the relative WVTR but can't measure the absolute value. The test should be conducted with the air gap within $6 \mathrm{~mm}$ in order to get the absolute value of WVTR for the enthalpy sheet by meeting the requirement prescribed.

\section{2 WVTR through porous enthalpy sheet}

Table 1 and Fig. 3 show the WVTR and the water vapor permeability according to the air gap of each type's moisture absorbent. The permeability is the characteristic considered in the water vapor partial pressure on both side of the sheets when having the test for moisture permeation and the thickness of the sheet.

The WVTR decreased as the treatment of moisture absorbent in some case, while the permeabilities of water vapor increased 5\%-20\% for the enthalpy sheets treated with moisture absorbents. The enthalpy sheet processed with $\mathrm{CaCl}_{2}$ and $\mathrm{LiCl}$ showed relatively high permeability of water vapor compared with the enthalpy sheet processed with silica. This is because moisture absorbent ability of $\mathrm{CaCl}_{2}$ and $\mathrm{LiCl}$ is relatively higher than that of silica so that the amount of the condensed water vapor permeated into the fiber increases. However, for porous enthalpy sheet, the water vapor mostly permeates throughout the pores. Therefore, the permeability of the water vapor under the water vapor partial pressure, in which there is little resistance when the water vapor permeates throughout the enthalpy sheet, is not influenced by the processing of the moisture absorbent.

Water vapor permeation throughout the porous enthalpy sheet consists of the movement throughout the pore existed inside and the movement by the condensation of fiber ${ }^{10)}$. The moisture absorbent can give the 
Table 1 WVTR through porous enthalpy sheets with different air gap

\begin{tabular}{|c|c|c|c|}
\hline & \multicolumn{3}{|c|}{ WVTR $\left(\mathrm{g} \mathrm{day}^{-1} \mathrm{~m}^{-2}\right)$} \\
\hline & \multirow{2}{*}{$6 \mathrm{~mm}$ air gap } & \multirow{2}{*}{13 mm air gap } & $W V T R_{6 \mathrm{~mm}}$ \\
\hline & & & $W V T R_{13 \mathrm{~mm}}$ \\
\hline Original & $2,053.29$ & 883.58 & 2.32 \\
\hline $5 \mathrm{wt} \% \mathrm{CaCl}_{2}$ & $1,948.83$ & 949.88 & 2.05 \\
\hline $5 \mathrm{wt} \% \mathrm{LiCl}$ & $2,182.04$ & 832.82 & 2.62 \\
\hline $5 \mathrm{wt} \%$ colloidal silica & $1,754.73$ & 651.20 & 2.69 \\
\hline
\end{tabular}

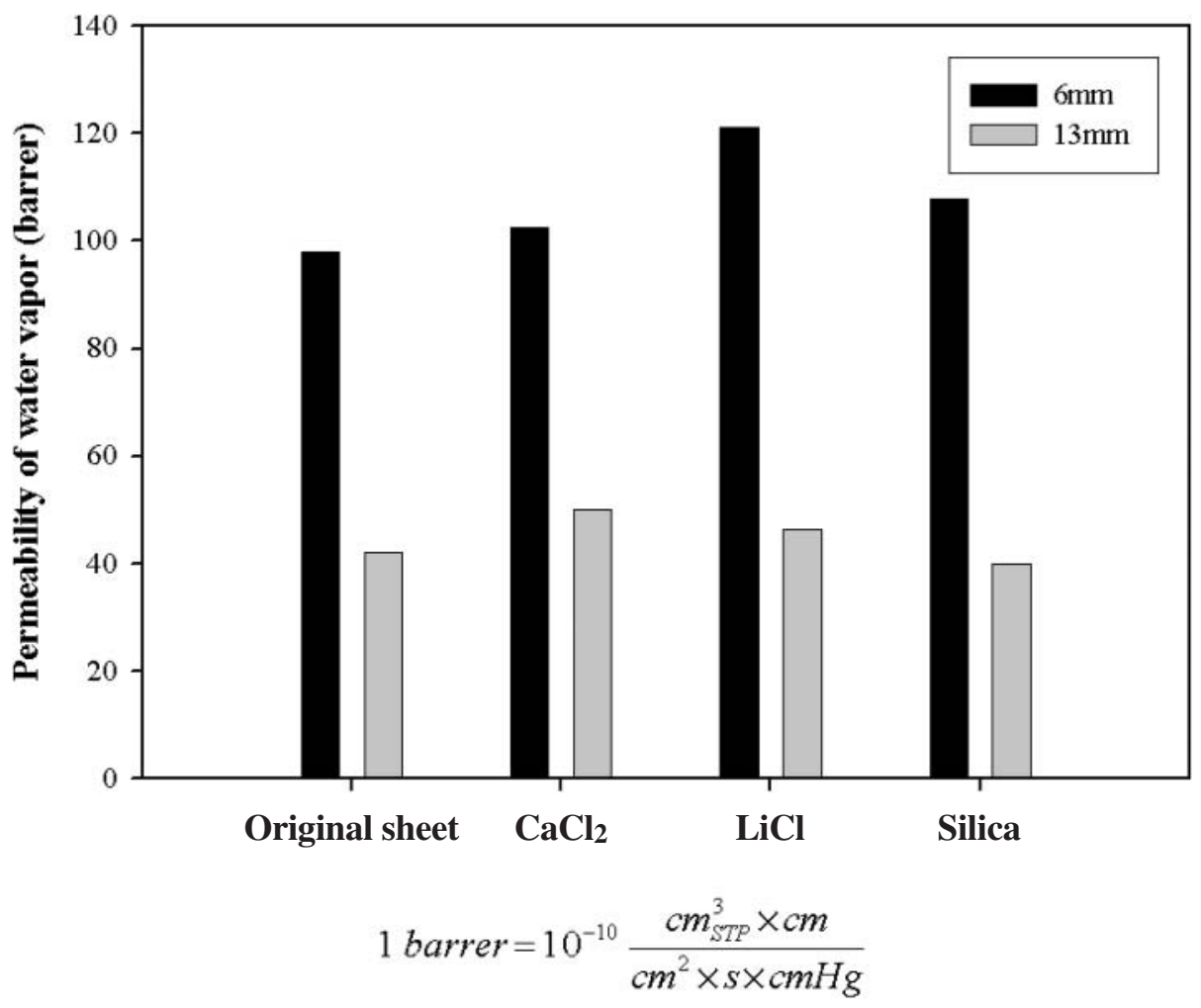

Fig. 3 Permeability of water vapor through porous enthalpy sheet.

positive effect to the movement by the condensation by increasing the moisture absorption while it can also give the negative effect obstructing the movement of the water vapor by blocking some of the pores on the surface of the enthalpy sheet, decreasing the pore size at the same time. Photo. 2 shows the SEM pictures of the surface of the porous enthalpy sheet before and after processing the moisture absorbent.

As shown in Figure, as the uptake of the moisture absorbent increases, the cellulose fiber on the surface of the enthalpy sheet is covered with the moisture absorbent, which turns out to operate as the additional resistance to the permeation of water vapor.

According to the processing of more than $1 \mathrm{~g} \mathrm{~m}^{-2}$ moisture absorbent, $\mathrm{LiCl}$ and $\mathrm{CaCl}_{2}$ showed the regular value of the permeability of water vapor (Fig.4). It showed the permeability increase caused by the main effect throughout the pore and additional effect throughout the moisture absorbent and also showed 


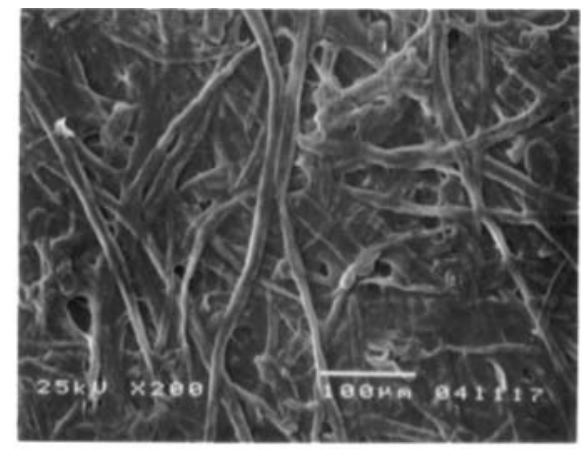

(a)

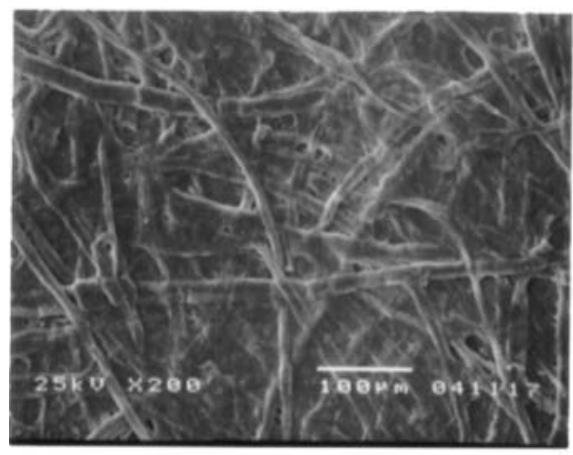

(c)

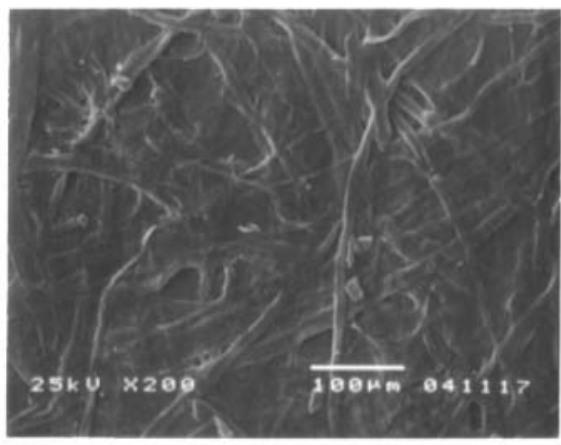

(b)

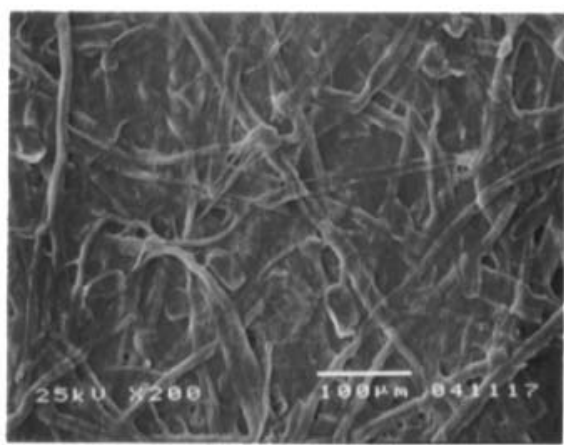

(d)

Photo.2 Scanning electron micrographs of porous enthalpy sheets : (a) untreated sheet, (b) $5 \mathrm{wt}_{\mathrm{C}} \mathrm{CaCl}_{2}$, (c) $5 \mathrm{wt} \% \mathrm{LiCl}$, and (d) $5 \mathrm{wt} \%$ collodial silica.

the increase of the amount of water vapor condensed by fiber as the increase of processing the moisture absorbent. However, the overall permeation showed the regular value since the moisture diffusion throughout the fiber is lower than that throughout the pore. For silica, it showed no increase of amount of permeation of water vapor as the amount of processing moisture absorbent increased. It is assumed that the hygroscopic property of silica is lower than that of $\mathrm{LiCl}$ and $\mathrm{CaCl}_{2}$.

\subsection{WVTR through dense enthalpy sheet}

Table 2 and Fig. 5 show the results of WVTR and water vapor permeability according to the changes of air gap on the dense enthalpy sheet. The distance between the enthalpy sheet and water surface is $13 \mathrm{~mm}$ and $6 \mathrm{~mm}$, just same as for the porous sheet. Different from the porous enthalpy sheet, the dense enthalpy sheet removed most of pores between fibers in order to exclude the mixture of the noxious gas from the indoor air when it is applied to the ventilation system. Therefore, it seems that the major factor causing the water vapor permeation is the condensation by fibers rather than diffusion by pores. As shown in figure, the permeability of water vapor showed more than 2 times of increase for all circumstances as the air gap decreased. As mentioned before, the distribution of water vapor pressure inside of the air gap became even as the air gap decreased so that it caused the increase of permeability. Furthermore, the water vapor permeability of the dense enthalpy sheet without processing moisture absorbent showed 1.3 to 1.7 times of increase according to the processing of the moisture absorbent. Different from the porous enthalpy sheet, the dense enthalpy sheet depends more on the movement by the dissolution than the moisture movement throughout the pores so the increase of 


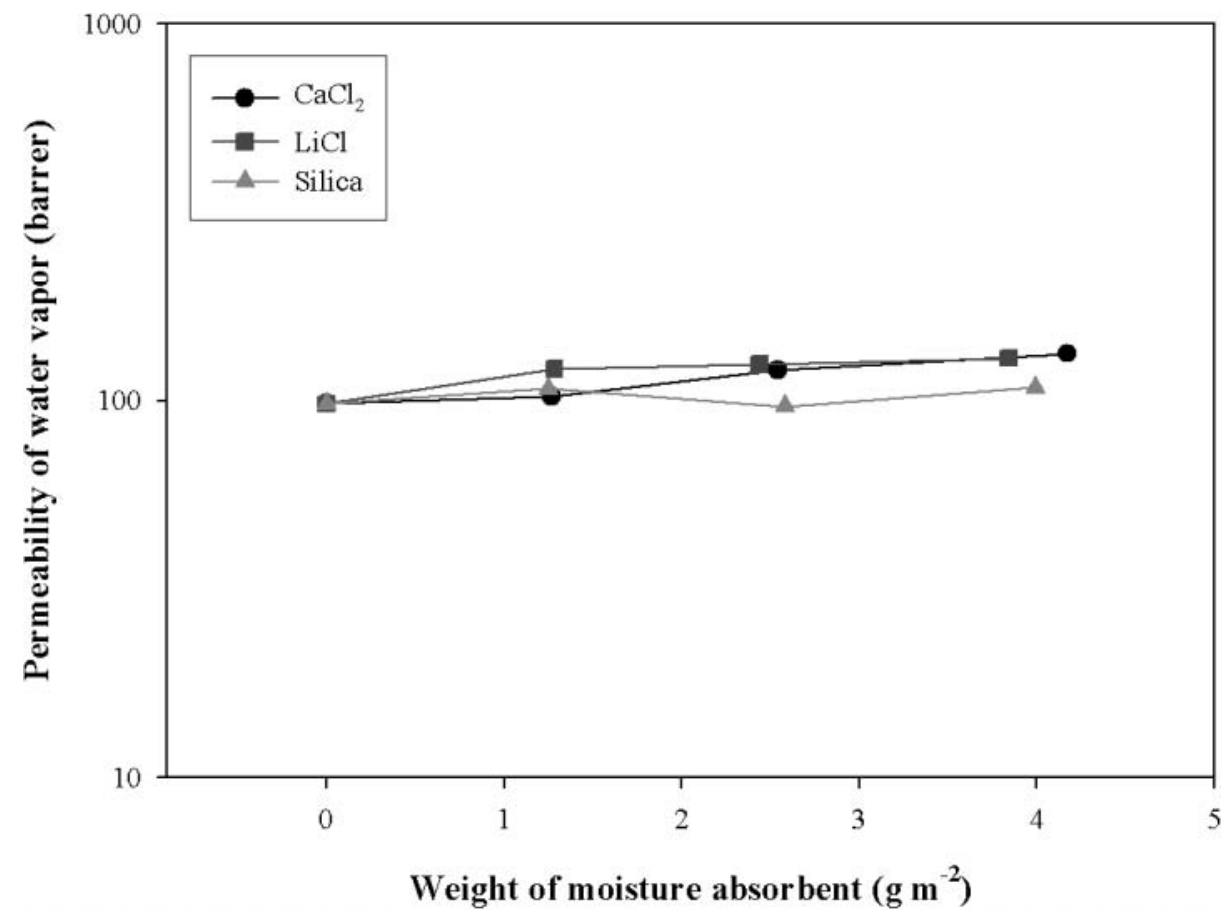

Fig. 4 Effect of moisture absorbent to permeability of water vapor through porous enthalpy sheet.

Table 2 WVTR vapor through dense enthalpy sheets with different air gap

\begin{tabular}{cccc}
\hline & \multicolumn{3}{c}{ WVTR $\left(\mathrm{g} \mathrm{day}^{-1} \mathrm{~m}^{-2}\right)$} \\
\cline { 2 - 4 } & $6 \mathrm{~mm}$ air gap & $13 \mathrm{~mm}$ air gap & WVTR $_{\text {6mm }}$ \\
\cline { 2 - 4 } & & & WVTR $_{13 \mathrm{~mm}}$ \\
\hline Original & $1,500.60$ & 658.42 & 2.27 \\
$5 \mathrm{wt} \% \mathrm{CaCl}_{2}$ & $1,947.28$ & 827.87 & 2.35 \\
5 wt\% LiCl & $1,930.62$ & 899.33 & 2.15 \\
5 wt\% colloidal silica & $1,520.87$ & 623.63 & 2.48 \\
\hline
\end{tabular}

moisture amount of the enthalpy sheet by moisture absorbent caused the overall increase of the permeability of water vapor. Comparing with the porous enthalpy sheet, it has about $70 \%$ of the permeability out of the porous enthalpy sheet's when not processing the moisture absorbent but it increased the same as the porous enthalpy sheet's when processing. Considering the possibility of mixing the noxious gas from the indoor air, the dense enthalpy sheet capable of excluding permeation of the noxious gas effectively is the enthalpy sheet with a high quality. Fig. 6 shows the permeation behavior of the dense enthalpy sheet for the permeability of water vapor according to the amount of processing moisture absorbent. All the circumstances processed with moisture absorbent, compared with ones without moisture absorbent process, showed the increase of the permeability of water vapor. As mentioned above, it seems to be caused by the increase of solubility of the water vapor by the moisture absorbent. Same as for the porous enthalpy sheet, it showed no more increase compared with the uptake of the moisture absorbent after certain amount of processing moisture absorbent. While the amount of the moisture of which the enthalpy sheet contains 


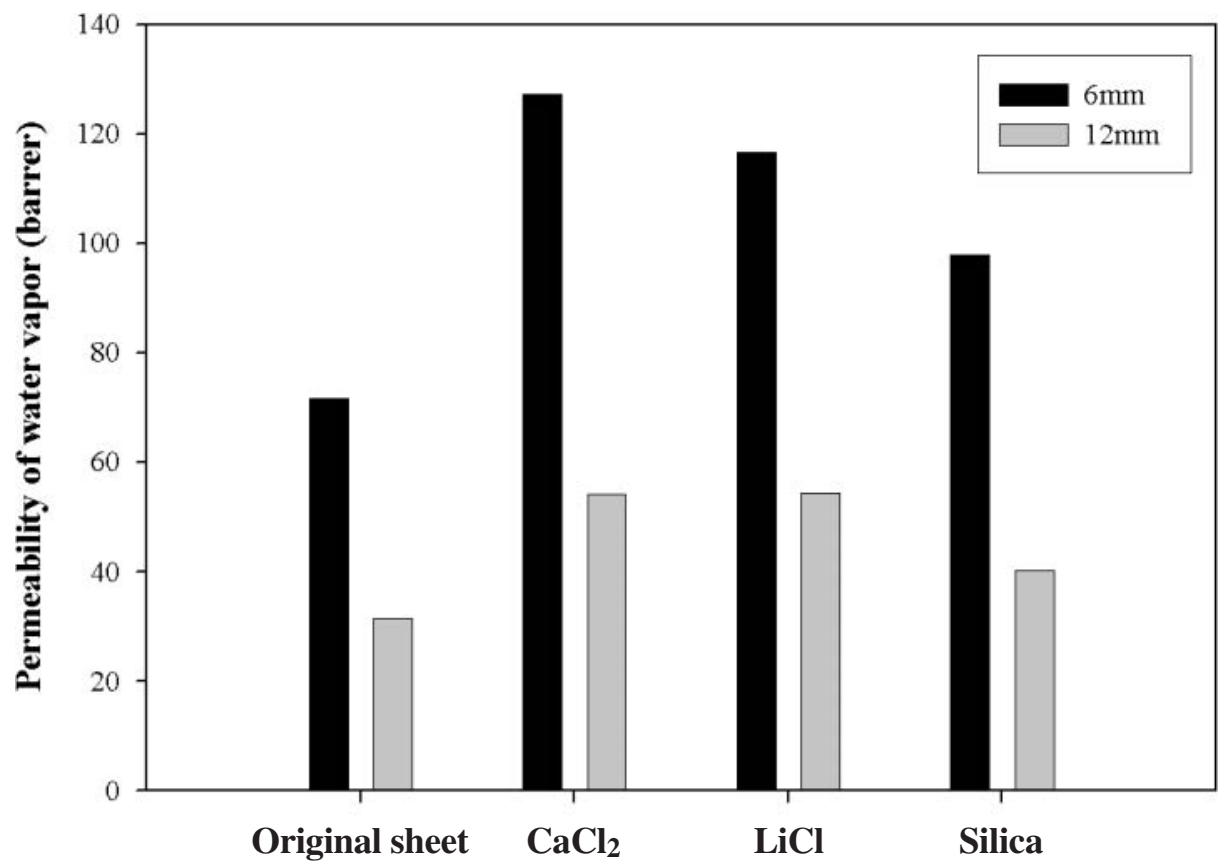

Fig. 5 Permeability of water vapor through dense enthalpy sheet.

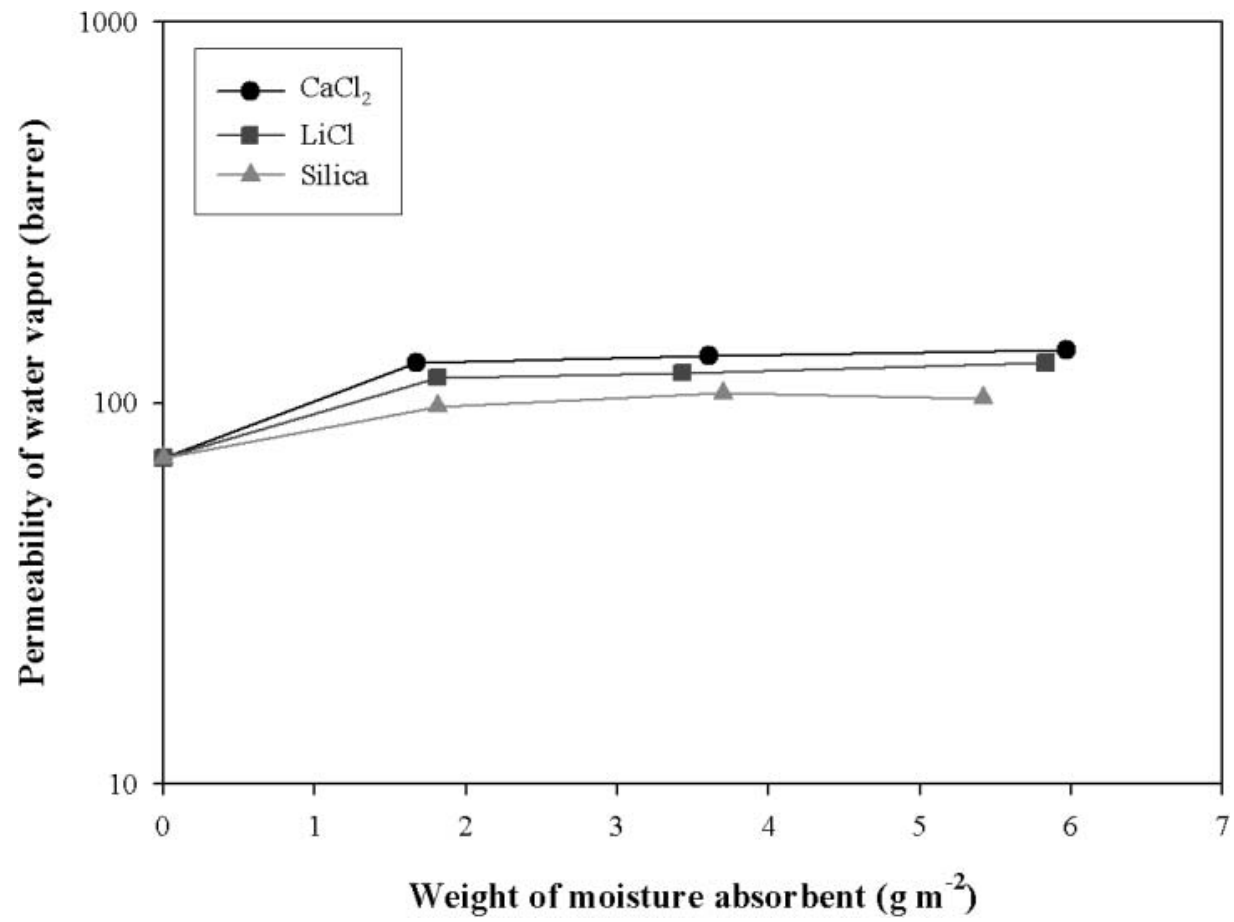

Fig. 6 Effect of moisture absorbent to permeability of water vapor through dense enthalpy sheet.

increased according to the processing of the moisture absorbent, the diffusivity speed, one that the moisture of the enthalpy sheet takes to permeate to the oppo- site side, became the rate determining step, showing the regular permeability.

Additionally, the surface of the enthalpy sheet got 


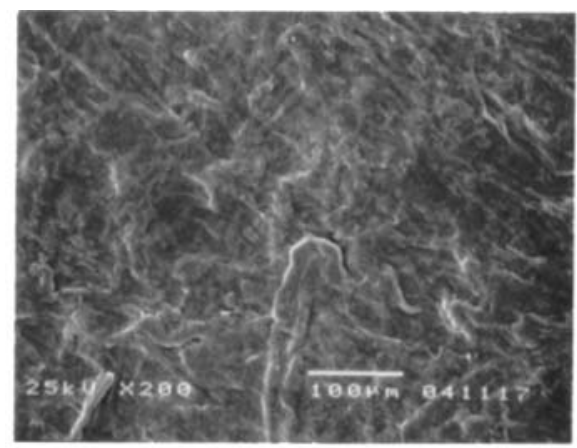

(a)

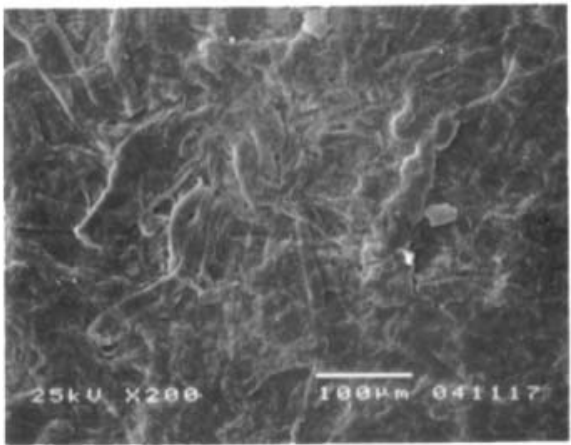

(c)

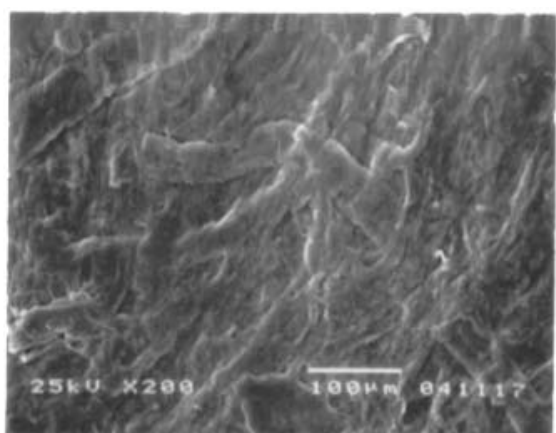

(b)

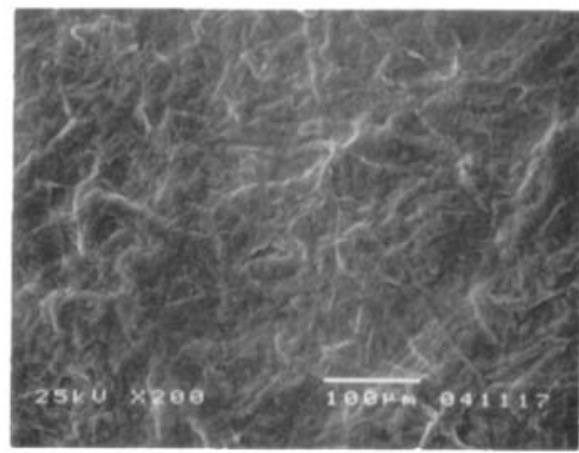

(d)

Photo. 3 Scanning electron micrographs of dense enthalpy sheets : (a) untreated sheet, (b) $5 \mathrm{wt} \% \mathrm{CaCl}_{2}, \quad$ (c) $10 \mathrm{wt} \% \mathrm{CaCl}_{2}$, and (d) $15 \mathrm{wt} \% \mathrm{CaCl}_{2}$.

covered with the moisture absorbent according to the processing moisture absorbent (Photo. 3). It could be said that this affect the permeability to become regular. However, different from the porous enthalpy sheet, it showed similar permeation efficiency to the porous enthalpy sheet when given little influence of pore block of the moisture absorbent since most of them are condensed in fiber and permeate.

\section{Conclusion}

The most important efficiency factor required for the enthalpy sheet is the high efficiency of moisture permeation and the ability to exclude noxious gas. Among the methods used to measure the efficiency of moisture permeation, ASTM 96-00 prescribes the wet cup method and the air gap is prescribed to be 19 $\mathrm{mm} \pm 6 \mathrm{~mm}$ on the tests but the quantitative evaluation for the efficiency of moisture permeation as the important factor of the enthalpy sheet is difficult because the permeability of water vapor increases according to the decrease of the air gap. Therefore, by reducing the air gap to $6 \mathrm{~mm}$ and examining the permeation efficiency of the enthalpy sheet, considering the permeation speed of the moisture in the air, the very close value to the real value of the water vapor transmission rate that enthalpy sheet has could be measured. Also the permeation characters of the water vapor for each of the two types of the enthalpy sheet used now, the porous and dense enthalpy sheet, were observed. On the porous enthalpy sheet, the water vapor permeation throughout the pores mainly happens so that there is not much influence caused by the processing of the moisture absorbent. On the other hand, there is relatively more influence caused by the moisture absorbent compared with the porous enthalpy sheet since the permeability of water vapor 
is determined by the behavior of solution-diffusion by the condensation of the cellulose fibers on the dense enthalpy sheet. With the improvement of the permeability of water vapor by processing the moisture absorbent, the efficiency of the dense enthalpy sheet for the latent heat exchange could be elevated up to that of the porous enthalpy sheet.

\section{Acknowledgement}

This work was supported by Korea Research Foundation Grant (KRF-2005-005-J01401).

\section{References}

1) H. B. Awbi, Ventilation of buildings, Chapman \& Hall, London, 1991

2) R. Besant and C. Simonson : ASHRAE Journal 45 (4) 42 (2003)

3) Y. Zhang, Y. Jiang, L. Z. Zhang, Y. Deng, and Z.
Jin : Energy 25, 515 (2000)

4) ASTM E 96-00, Standard Test Methods for Water Vapor Transmission of Materials, 2000

5) JRAIA/JSA : JIS B 8628,2000

6) ASHRAE, ASHRAE Standard 84-78 (1978)

7) E. M. Sparrow, J. P. Abraham, G. P. Martin, and J . C. Y. Tong : Int. J. Heat Mass Transfer 44, 4313 (2001)

8) Y. Hu, V. Topolkaraev, A. Hiltner and E. Baer, J. Appl. Polym. Sci. , 81, 1624-1633 (2001)

9) R. M. Lazzarin, A. Gasparella and G. A. Longo : Int. J. of Refrigeration 22, 334-347 (1999)

10) S-H. Yoon, S-D. Sohn, and B-C. Lee : J. Ind. Eng. Chem., 9 (6) 647 (2003)

(受理 : ’05.8.16)

以下の翻訳は，紙パ技協誌読者の便宜のために，著者の了解のもとに紙パルプ技術協会が翻 訳したものである。翻訳の文章は紙パルプ技術協会のものであるが，その内容に関してはあく までオリジナルが正であり，翻訳に基づく内容に関する議論またはそれに基づく結果に紙パル プ技術協会が責任を持つものではない。

\section{1. 緒言}

1970 年代のオイルショックを経て, エネルギー効 率化の必要性は急速に増加してきた。このため熱利用 の効率化の研究は継続的に進められ, 建造物の高気密, 高断熱化が進んでいる。屋内空気品質を健康的に保つ ために必要とされる自然換気の割合は, 場所に依存し て 2 ないし 5 回であるが, 省エネルギー化への関心の 高まりからすればこれでは不十分である ${ }^{1)} 。$

空調用熱交換器は省エネルギーと室内空気品質向上 の両方を満足させる換気装置であり，ほとんどの空調 設備に装着されている。熱交換器は, その熱交換素子 によって 2 種に分類できる。ひとつは金属やプラスチ ックで作られた顕熱のみを交換するもので，もうひと つは紙や蓄積された熱に対応する素材による, 顕熱と 潜熱を同時に交換できる全熱交換器である。また全熱
交換器は浸透板, energy wheel と回転式除湿機に分 類できる ${ }^{2-4)}$ 。これらの全熱交換器の中でも, 吸気と排 気ファンで構成され可動部を必要とせず, 天井内にも 設置できる単純な浸透板タイプのものが利用の大半を 占める。

このような使用の増加とは逆に, 全熱交換機の中枢 である全熱交換素子の開発のための評価基準は，それ らの性能に関する研究や規格が熱交換素子の種類によ って区別されるため，充実しているとは言い難い ${ }^{5-7)}$ 。 熱交換紙の優れた特性とは, 水蒸気の透過量を最大化 し，有害ガスの透過を最小化することにより，熱交換 性能を向上させる所にある。従って, 高品質の熱交換 器を作成するには, 事前に熱交換素子の性能評価を行 うべきである。これらの両パラメータにおいて, 水蒸 気透過速度 (WVTR) が最も重要な要素である。蓄 積された熱を測定する水蒸気透過度試験を規定する試 
験法は ASTM 96-00 および JISである。またこれら の試験は, 水で満たされたセルの内から外への透過量 を測定するウェットカップ法と, $\mathrm{CaO}$ で満たされた セルの内への吸収量を測定するドライカップ法で構成 される ${ }^{5,6)}$ 。ただし水の浸透によって起きる抵抗, 試料 そのものの抵抗および試料両面から空気層への境界面 抵抗の測定法についての研究が不足しているため, こ れら両試験法で決定できるのは相対的な水蒸気透過速 度のみである ${ }^{8)}$

従って本研究では, 熱交換効率に影響する水蒸気透 過度を調べるため従来の規格を見直し, 改良した方法 で熱交換紙の性能を測定した。熱交換紙の水蒸気透過 速度は, 機器への取付け以前に調べている。

多孔性および緻密熱交換紙を評価することにより， 多孔構造に依存した水蒸気透過速度と, 主に液状乾燥 剂に利用される $\mathrm{CaCl}_{2}, \mathrm{LiCl}$, コロイダルシリカ等の 吸湿剂の影響が調べられた9?

\section{2. 実験}

\section{1 熱交換紙の調製}

吸湿剂として, 市販の無水 $\mathrm{CaCl}_{2}$ (chemical pure grade）及び無水 $\mathrm{LiCl}$ (extra pure grade）（共に Junsei Chemical Co., Ltd）をさらに精製して使用した。 またコロイダルシリカも市販品 (snowtechs 20, Nissan Chemical Industries Co., Ltd）（安定剂 Na, 粒子 径 10-20 nm, pH 9. 5-10, 粘度 1. 0-3.0 mPs, 固形分 20\%）を用いた。

多孔性及び緻密性熱交換紙は, 三菱製紙株式会社か ら提供された吸湿剂未処理のものを使用し，超純水を 浸漬に使用した。

吸湿剂の浸漬工程は下記の通り。先ず吸湿剤溶液を 目的の濃度で調整し, 標準サイズ $(6 \mathrm{~cm} \times 6 \mathrm{~cm})$ の 熱交換紙を秤量し，ペトリ皿中で $300 \mathrm{ml}$ の溶液に 3 分間浸漬した。環境は $20^{\circ} \mathrm{C} ， 20 \% \mathrm{RH}$ であった。こ の間吸湿剤溶液が空気中の水分を吸収しないよう蓋で 覆った。その後シートを取り出しガラス板上に置き, ゴムローラーでシート上の吸湿剤を除いた。水分の蒸 発に考慮してシート重量を速やかに測定した。シート をホットプレート上で乾燥し, 平滑に保つため 120 $130^{\circ} \mathrm{C}$ で熱処理を行った。厚さの測定值は厚さ計 (Mitutoyo, Japan）によりシート上の最低 5 箇所から得た。 各試料の厚さの標準偏差は通常 $10 \%$ 以下であった。 吸湿剂の定着量は以下の式により決定した。

Absorbent uptake $=\left(W_{\text {wet }}-W_{d r y}\right) \times C_{\text {absorbent }}$

$W_{\text {wet }}$ は余剩水分を除いた未乾燥シートの重量, $W_{d r y}$ は 乾燥シート重量, $C_{\text {absorbent }}$ は吸湿剂の重量濃度である。

\section{2 水蒸気透過度測定}

水蒸気透過度 (WVTR) 測定の実験装置の模式図 を図 1 に示す。WVTRの測定法は, ASTM E 96-00 によるウェットカップ法の改良版である ${ }^{4)}$ 。この測定 法では, 試験フィルムは超純水を満たしたペトリ皿上 を覆う。皿から失われた水分量は時間の関数として得 られ，WVTRが算出された。面積既知の空をアクリ

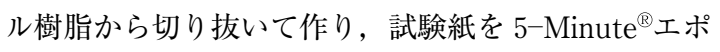
キシにより接着した。試験紙のついたアクリル樹脂は アルミテープで $38.5 \mathrm{~cm}^{2}$ のペトリ皿上部に接着した。 シリンジを用いて $48.2 \mathrm{ml}$ の超純水を注入し, アル ミテープで穴をふさいだ。このときの水面と試験紙の 距離は $6 \mathrm{~mm}$ であった。空隙幅の影響を調べるため, 距離が $13 \mathrm{~mm}$ の場合もWVTRの測定を行った。エ ポキシのキュアのため 1 時間放置した後試験体を秤量 し, $25 \pm 0.5^{\circ} \mathrm{C}, 50 \pm 1.5 \% \mathrm{RH}$ の恒温恒湿条件に置い た。換気率は約 $0.5 \mathrm{~m} \mathrm{~s}^{-1}$ であった。試験体は 1 時間 おきに恒温恒湿器から取り出して秤量し, 重量の減少 を時間の関数として測定した。

\section{3. 結果と考察}

\section{1 水蒸気透過度}

多孔紙, 緻密紙および $\mathrm{CaCl}_{2}$ 処理の緻密紙について のテスト結果を図 2 に示す。時間経過と水分の減少量 の関係は直線状であり, 水蒸気透過が一様であること を示している。すべての試験は, 恒温恒湿条件に 8 時 間以上置かれたためと, 水蒸気透過度が一般条件での 水分減少から得られたことから, 正常であると確認さ れた。試験体内の湿度が試験温度での定常状態に達す るまで 1 時間を要し, その後はすべての試験で一定と なった。

試験面積について正規化された時間関数としての WVTR は次のように計算できる。単位は $\mathrm{g} \mathrm{day}{ }^{-1} \mathrm{~m}^{-2}$ である。

$$
\text { WVTR }=\frac{\text { mass } \mathrm{H}_{2} \mathrm{O} \text { lost }}{\text { time } \times \text { area }}=\frac{\text { flux }}{\text { area }}
$$

WVTR は材料特性, 即ち水蒸気透過度りと次のよ うに関系している。また単位は $\mathrm{cm}^{3} \mathrm{~cm} \mathrm{~cm}^{-2} \mathrm{~s}^{-1} \mathrm{cmHg}^{-1}$ である。

$$
\wp=W V T R\left(\frac{l}{\Delta p}\right)
$$

$l$ はシート厚さ $(\mathrm{cm}), \Delta p$ はシート内外の圧力差 $(\mathrm{cmHg})$ である ${ }^{4)}$ 。

写真 1 に多孔紙における, 空隙幅に依存するWVTR 変化を示した。ASTM 96-00 規格のウェットカップ テストでは, 試料と水面間の距離は $19 \pm 6 \mathrm{~mm}$ と規定 
されている4。この規定では，テストセル内部の試料 と水面間では湿度が $100 \%$ と見なされている。しかし ながら図 3 のとおり, 空隙幅が $6 \mathrm{~mm}$ の場合には規定 の最小值である $13 \mathrm{~mm}$ に比べて 2 倍以上の WVTR 值を示している。空隙幅に伴いWVTR が異なる值を 示すということは, 水面から試料表面へ水蒸気が上昇 する際，濃度勾配が存在することによる抵抗を受ける ことを示している。

HuらはSchirmerの式により静止した空気層での 水分浸透を計算している8。

$$
\xi_{\text {air }}=\left[\frac{\left(2.306 \times 10^{-5}\right) P_{0}}{R_{\mathrm{v}} T P}\right]\left[\frac{T}{273.15}\right]^{1.81}
$$

$T$ は温度 $(\mathrm{K}), P$ は周囲の気圧 $(\mathrm{Pa}), P_{0}$ は標準気 圧 $(101,325 \mathrm{~Pa}), R_{v}$ は理想気体定数 $\left(461.5 \mathrm{~J} \mathrm{~K}^{-1} \mathrm{~kg}^{-1}\right.$ for water）である。水蒸気透過速度は透過度から次 のようにして得られる。

$$
\text { WVTR } \frac{\wp_{a i r} \Delta P}{W}
$$

$W$ は空隙幅, $\Delta P$ は 2 面間の圧力差である。この式 より, 空隙幅 $6 \mathrm{~mm}$ という条件がテストセル内部の静 止空気層への水蒸気透過度を計算する上で最適值であ ると判明した。ASTM 規格に規定される試験法では 相対的な WVTR は測定できるが，絶対值については 不可能である。WVTRの規定を満足する絶対值を得 るために空隙幅は $6 \mathrm{~mm}$ 以内で試験を行うべきである。

\section{2 多孔紙の WVTR}

表 1 と図 3 に, 多孔紙の空隙幅によるWVTR およ び水蒸気透過度変化を各吸湿剂処理及び未处理紙につ いて示した。水蒸気浸透性は, 水分浸透とシート厚が 既知である場合にシート両面の水蒸気分圧に関連して 得られる特性である。

吸湿剂処理によってWVTR は減少したものもあっ たが, 水蒸気透過度は 5-20\%の増加が見られた。 $\mathrm{CaCl}_{2}$ および $\mathrm{LiCl}$ 処理のシートはシリカ処理に比べて高い 水蒸気浸透性を示した。これは $\mathrm{CaCl}_{2}$ および $\mathrm{LiCl}$ の 吸湿特性がシリカより比較的高いために, 繊維に凝結 して浸透した水蒸気が増加したためと考えられる。し かし多孔紙においては, 水蒸気はほほ全量が細孔中を 透過する。従ってシート中を透過する際にほとんど抵 抗を持たないような水蒸気分圧下では, 吸湿剂処理に よる浸透性への影響は無い。

多孔紙中の水蒸気透過は, 内部細孔中の透過と繊維 への凝結による移動から成る ${ }^{10)}$ 。吸湿剂は凝結の増加 により水蒸気透過に対して促進効果を持つが, シート 表面の細孔の被覆, 及び細孔のサイズ減少という形で 阻害効果も併せ持つ。写真 2 に吸湿剂处理後の多孔紙
の SEM 写真を示した。

図のとおりシート表面のセルロース繊維は吸湿剂に 覆われ, 吸収される水分は増加するが，このことが同 時に水蒸気浸透にとって新たな抵抗として作用する。

$\mathrm{LiCl}$ および $\mathrm{CaCl}_{2}$ 処理においては, 処理量が $1 \mathrm{~g} \mathrm{~m}^{-1}$ を超えた場合, 水蒸気浸透性は一定の值を示した（図 4)。これは多孔紙への水蒸気浸透の増加は主として細 孔中への影響に依存して起こり, 吸湿剂は副次的な効 果であること, また処理量の増加に伴い繊維に凝結す る水分量が増加したことを示している。しかし, 繊維 中への水分拡散は細孔中の透過より少ないために透過 度全体としては一定となる。シリカについては, 処理 量の増加による透過度の増加は見られなかった。シリ カの吸湿性は $\mathrm{LiCl}$ および $\mathrm{CaCl}_{2}$ よりも低いと考えら れる。

\section{3 緻密紙の WVTR}

表 2 と図 5 に緻密紙における空隙幅とWVTRの関 係を示した。空隙幅は多孔紙と同じく $13 \mathrm{~mm}$ および $6 \mathrm{~mm}$ である。多孔紙と違い, 緻密紙は換気系に使用 する際室内気からの有害ガス混合物の混入を防ぐため, 繊維間の細孔は排除されている。従って, 水蒸気透過 は繊維への凝結が主たる要素になると考えられる。図 のとおり, WVTR は空隙幅の隇少に伴い全てのサン プルで 2 倍以上の増加を示した。前述のとおり空隙幅 の減少に伴い空隙内で水蒸気分圧が一定となり, 透過 度の増加が起きた。さらに, 吸湿剂処理によって 1.3 から 1.7 倍の水蒸気透過度の増加を示している。多孔 紙とは異なり, 緻密紙の水分浸透の要因は溶解による 移動によるところが大きい。よって吸湿剤によるシー 卜中の水分量の増加は, 全水蒸気透過度の増加の原因 となる。吸湿剂未処理の緻密紙は, 未処理の多孔紙に 比して $70 \%$ 程度の浸透性を持つが, 処理後は多孔紙 と同程度まで増加している。室内気からの有害ガスの 混入の可能性を考えれば, 効率的に有害ガスの浸透を 防除できる緻密紙は高品質である。図 6 は吸湿剂処理 量による緻密紙の水蒸気浸透性変化を示している。全 てのサンプルで未処理時に比較して透過度の増加が見 られた。上記のとおり,これは吸湿剤により水蒸気の 溶解性が増加したためと考えられる。また多孔紙と同 じく, ある量以上の処理においてはそれ以上の浸透性 増加は見られなかった。吸湿剂処理量に伴いシート中 の水分量は増加しているが, 紙中の水分が反対側に達 するまでの時間といった拡散速度が律速段階となり, 一定の值を示している。

さらに, 吸湿剂処理によりシート表面は覆われる(写 真 3)。このことが浸透性を一定にするよう影響して 
いると言える。しかし多孔紙と違い, 大部分の水蒸気 は繊維に凝結して透過するため細孔被覆の影響がほと んど無く, 多孔紙に近い透過効率を示している。

\section{4. 結 論}

全熱交換紙に求められる最も重要な性能は, 高い水 蒸気の透過率と有害ガスの防除能である。水蒸気透過 率を測定する試験法の中では, ASTM 96-00 がウェ ットカップ法を規定し, 空隙幅を $19 \pm 6 \mathrm{~mm}$ としてい るが, 熱交換紙の重要な性能である水蒸気浸透率は, 空隙幅の減少に伴って増加するため定量的な測定は困 難である。従って空隙幅を $6 \mathrm{~mm}$ まで減少させ, 透過
効率を計測し, 空気中の水蒸気透過速度を考慮するこ とで熱交換紙の持つ真の水蒸気透過速度に近い值を測 定することができた。また現在使用されている多孔及 び緻密 2 種の熱交換紙について透過特性が得られた。 多孔紙においては, シート内の細孔中への水蒸気浸透 が主として発生し, 吸湿剂処理の影響は小さい。一方 緻密紙においては緘維への凝結と溶解, 拡散挙動によ り水蒸気浸透性が決定されるため, 吸湿剤処理により 比較的大きな影響を受ける。吸湿剂処理により, 潜熱 交換器に使用する緻密紙の水蒸気透過率を多孔紙と同 等な水準まで向上させることができた。 